\title{
Risk factors for mortality in patients with Clostridium difficile
} infection

\author{
Elizabeth Pérez-Cruz ${ }^{1 *}$ and María Graciela Sandoval-Flores ${ }^{2}$
}

${ }^{1}$ Critical Medicine Division; ${ }^{2}$ Internal Medicine, Secretaría de Salud, Hospital Juárez de México. Mexico City, Mexico

\begin{abstract}
\end{abstract}
Introduction: Clostridium difficile infection (CDI) causes potentially lethal diarrhea. Objective: To identify the risk factors for mortality in hospitalized patients with CDI. Method: Cross-sectional, retrospective study. The analyzed risk factors wereáge, comorbidities, nutritional status, past and current use of antibiotics, proton pump inhibitors, steroids, immunosuppressive therkapy and chemotherapy, as well as development of acute kidney injury (AKI). Results: Sixty-eight cases were assessed. Meañage was $51.4 \pm 19.37$ years. Mortality was $22.2 \%$. Moderate to severe undernutrition (Odds ratio [OR] = 20.15; 95\% confidence interval $[C l]=1.13-35 ; p=0.004)$, use of more than 2 antibiotics $(O R=1.61 ; 95 \% \mathrm{Cl}=0.39-6.65 ; p=0.01)$, AKI as determined by creatinine levels $(O R=1.34 ; 95 \% \mathrm{Cl}=0.09-2.21 ; p=0.02)$, hypotension with vasopressor use $(O R=1.28 ; 95 \% \mathrm{Cl}=0.30$ 1.23; $p=0.001)$ and multiple organ failure $(O R=1.13 ; 95 \% \mathrm{Cl}=0.31-4.92 ; p=0.002)$ were associated with mortality. Conclusions: $C D I$ represents an important problem in hospitalized patients and confers them an additional morbidity and mortality risk.

KEY WORDS: Diarrhea. Clostridium difficile. Mortality.

\section{Introduction}

Clostridium difficile infection (CDI) is a common cause of infectious diarrhea in hospitalized patients, and it is potentially lethal ${ }^{1}$ Epidemiological studies have shown that it has replaced methicillin-resistant Staphylococcus aureus as healthcare-associated infection. ${ }^{2} \mathrm{CDI}$ incidence at hospital centers is increasing; in the United States, it went from 3.82 cases per 1000 hospital discharges in the year 2000 to 8.75 in 2008, with the most affected age group being subjects older than 65 years. ${ }^{3,4}$ In 2008, the European Centre for Disease Prevention and Control established a surveillance system for CDI in 34 European countries, whereby an incidence of 5.5 cases per 10,000 patient-days was identified. ${ }^{5,6}$ In Latin America, there are only few epidemiological studies on CDI; in a review, Freeman and Bauer ${ }^{5}$ reported an incidence ranging from 37 to 84 cases per 10,000 admissions between 2000 and 2005. Mortality due to CDI hisas also increased: from 2.0 deaths per 100,000 cases in 2007 to 2.3 in 2008, which represents a $15 \%$ increase. ${ }^{1}$ In Mexico, Ramírez et al. ${ }^{7}$ reported a CDF-associated mortality of $10 \%$ in a private hospital.

The risk factors associated with CDI include age > 65 years, $^{8}$ neoplasms, diabetes mellitus, chronic kidney disease, immunodeficiency, transplantafion, previous exposure to antibiotics, use of chemotherapy, immunosuppressants, proton pump inhibitors and previous gastrointestinal surgery. ${ }^{3,9}$ Mortality predictors include age $>65$ years, severe infection, organ faillure with vasopressor use, need for mechanical ventilation, hyperlactatemia, mental state alterations and absence of vancomycin in patient treatment. ${ }^{10}$ Currently, vañcomycin and metronidazole are offered as effective drugs for the management of patients with CDI. Timely identification of mortality risk factors will allow early intervention and reduce CDI-attributed mortality. ్he
Date of reception: 17-04-2018

Date of acceptance: 27-03-2019

DOI: 10.24875/GMM.M19000295 
purpose of this study is to identify the risk factors for in-hospital mortality in hospitalized patients with CDI.

\section{Method}

Retrospective, cross-sectional study at a high-specialty reference hospital in Mexico, which comprised the period between January 2015 and April 2017. Patients hospitalized at medical and surgical departments who met the following criteria were included: both genders, older than 18 years and with CDI-associated diarrhea. Diarrhea was defined as the presence of three or more bowel movements in 24 hours, and the $\mathrm{CDI}$ diagnosis was based on the detection of toxins A or B by immunoassay, PCR for Clostridium difficile or rapid test by immune chromatography for Clostridium difficile glutamate dehydrogenase qualitative detection. Patients who used laxatives, and those with incomplete data, were excluded.

Data were extracted from medical records using a predesigned spreadsheet. Demographic variables, CDI diagnostic method and risk factors such as age, comorbidities, nutritional status, history (30 previous days) of antibiotic, proton pump inhibitors, steroids, immunosuppressants and chemotherapy use were recorded, as well as development of acute kidney injury; procalcitonin levels and days of hospital stay were also recorded.

Nutritional status was assessed considering serum albumin, prealbumin and transferrin levels, with the following classification:

- Mild malnourishment, albumin from 3 to $3.4 \mathrm{~g} / \mathrm{dL}$, prealbumin 10 to $15 \mathrm{mg} / \mathrm{dL}$ and/or transferrin 150 to $200 \mathrm{mg} / \mathrm{dL}$

- Moderate malnourishment, albumin from 2.9 to $2.1 \mathrm{~g} / \mathrm{dL}$, prealbumin 5 to $10 \mathrm{mg} / \mathrm{dL}$ and/or transferrin 100 to $150 \mathrm{mg} / \mathrm{dL}$

- Severe malnourishment, albumin $<2.1 \mathrm{~g} / \mathrm{dL}$, prealbumin $<5 \mathrm{mg} / \mathrm{dL}$ and/or transferrin $<100 \mathrm{mg} / \mathrm{dL}$.

For the analysis of dichotomous variables, the following groups were established:

- Without malnourishment or mild malnourishment

- Moderate or severe malnourishment.

Acute kidney injury was determined based on the Acute Kidney Injury Network (AKIN) diagnostic criteria, i.e., with renal function sudden reduction in 48 hours, serum creatinine increase $\geq 0.3 \mathrm{mg} / \mathrm{dL}$ or $\geq 50 \%$, or urinary volume reduction $<0.5 \mathrm{~mL} / \mathrm{kg} /$ hour for more than six hours; dichotomous variables were analyzed as absent or present.
CDI severity was stratified according to the classsification proposed by the Infectious Diseases Society of America (IDSA) guidelines:

- Mild, CDI with diarrhea as only symptom

- Moderate, CDI with diarrhea, but without sigñ symptoms of severe or complicated disease-

- Severe, CDI with hypoalbuminemia $(<3 \mathrm{~g} / \mathrm{dL}$ ) plus one of the following parameters: leukocytes $\geq 15,000$ cells $/ \mathrm{mm}^{3}$ or abdominal pain without criteria consistent with complicated disease

- Complicated, CDI plus intensive care unit admission, hypotension with or without vasopressors, fever $\geq 38.5^{\circ} \mathrm{C}$, ileus or important abdominal distension, mental state changes in, leukocỹtes $\geq 35,000$ cells $/ \mathrm{mm}^{3}$ or $<2000$ cells $/ \mathrm{mm}^{3}$, serum lactate $>2.2 \mathrm{mmol} / \mathrm{L}$ or any evidence of êndstage organ failure.

Descriptive statistics were used for population demographic and clinical characteristics. For quaritative variables, the chi-square test was used, and for categorical variables, contingency tables and Student's t-test. Patients were divided into two groups for risk factor analysis and for magnitude of association determination: alive patients and those who died. Statistical significance was considered with a $\mathrm{p}$-value $<0.05$. Data were analyzed with the SPS statistical program, version 24.0. The study was conducted in compliance with the provisions of the General Statute of Health and was accepted by the research committee of the hospital with institutional registration.

\section{Results}

Out of 26,420 hospital admissions in the study period, CDI diagnostic criteria were met in 68- $\mathrm{dpa}$ tients, with an incidence of 25.7 cases per 10,000 hospital discharges. Out of total patients, five were excluded due to incomplete data, $63.5 \%(n=40)$ were females and $36.5 \%(n=23)$ were males. Mean age was $51.4 \pm 19.37$ years, with a range between 19 and 91 years. Table 1 describes the demographic characteristics. Mortality was $22.2 \%(n=14)$.

CDI diagnosis by rapid test was $66.1 \%$, by PCR, of $44.4 \%$ and by toxin $A$ and $B$ determination, $6.3 \%$. Hospital departments with higher CDI reports were internal medicine $(28.6 \%)$, geriatrics $(20.6 \%)$, hematóogy (12.7\%) and rheumatology (11.1\%).

As for disease severity, in $34.9 \%$ it was mild in $11.1 \%$, moderate, in $6.3 \%$, severe and in $47.6 \%$ it was complicated disease. Regarding the patients who 
Table 1. Demographic characteristics of patients with CDI-associated diarrhea, hospitalized in medical and surgical areas

\begin{tabular}{|c|c|c|c|c|c|c|c|}
\hline Characteristic & \multicolumn{2}{|c|}{ Alive $(n=49)$} & \multicolumn{2}{|c|}{ Dead $(n=14)$} & \multicolumn{2}{|c|}{ Total $(n=63)$} & $\underset{1}{2}$ \\
\hline \multirow[t]{2}{*}{ Age (years) } & \multicolumn{2}{|c|}{$50 \pm 19.2$} & \multicolumn{2}{|c|}{$56.4 \pm 19.9$} & \multicolumn{2}{|c|}{$51.4 \pm 19.3$} & ટ \\
\hline & $\mathrm{n}$ & $\%$ & $n$ & $\%$ & $\mathrm{n}$ & & है \\
\hline Females & 31 & 63.3 & 9 & 64.3 & 40 & & 50 \\
\hline $\begin{array}{l}\text { Hospital department } \\
\text { Internal medicine } \\
\text { Geriatrics } \\
\text { Hematology } \\
\text { Rheumatology } \\
\text { Surgical areas } \\
\text { Other }^{\star *}\end{array}$ & $\begin{array}{l}16 \\
9 \\
6 \\
4 \\
5 \\
9\end{array}$ & $\begin{array}{c}32.7 \\
18.4 \\
12.2 \\
8.2 \\
10.2 \\
18.3\end{array}$ & $\begin{array}{l}2 \\
4 \\
2 \\
3 \\
1 \\
2\end{array}$ & $\begin{array}{c}14.3 \\
28.6 \\
14.3 \\
21.4 \\
7.1 \\
14.3\end{array}$ & $\begin{array}{c}18 \\
13 \\
8 \\
7 \\
6 \\
11\end{array}$ & $\begin{array}{r}28 \\
20 \\
12 \\
11 \\
9 \\
17\end{array}$ & 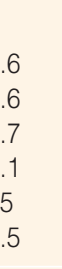 \\
\hline $\begin{array}{l}\text { Comorbidities } \\
\text { None } \\
\text { Diabetes mellitus } \\
\text { Hematologic and solid neoplasms } \\
\text { Rheumatic diseases } \\
\text { Other }\end{array}$ & $\begin{array}{c}9 \\
20 \\
10 \\
6 \\
8\end{array}$ & $\begin{array}{c}18.36 \\
40.8 \\
20.4 \\
12.2 \\
16.3\end{array}$ & $\begin{array}{l}3 \\
3 \\
3 \\
3 \\
3\end{array}$ & $\begin{array}{l}21.4 \\
21.4 \\
21.4 \\
21.4 \\
21.4\end{array}$ & $\begin{array}{c}12 \\
23 \\
13 \\
9 \\
11\end{array}$ & $\begin{array}{l}19 \\
36 \\
20 \\
14 \\
17\end{array}$ & 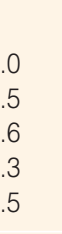 \\
\hline $\begin{array}{l}\text { Admission diagnosis } \\
\text { Nosocomial pneumonia } \\
\text { Urinary tract infection } \\
\text { Community-acquired pneumonia } \\
\text { Fever and neutropenia } \\
\text { Other }{ }^{\ddagger} \\
\text { Non-infectious }\end{array}$ & $\begin{array}{c}12 \\
12 \\
6 \\
6 \\
9 \\
4\end{array}$ & $\begin{array}{c}24.5 \\
24.5 \\
12.2 \\
12.2 \\
18.4 \\
8.2\end{array}$ & $\begin{array}{l}5 \\
1 \\
2 \\
1 \\
4 \\
1\end{array}$ & $\begin{array}{c}35.8 \\
7.1 \\
14.3 \\
7.1 \\
28.6 \\
7.1\end{array}$ & $\begin{array}{c}17 \\
13 \\
8 \\
7 \\
13 \\
5\end{array}$ & $\begin{array}{r}2 \\
20 \\
12 \\
11 \\
20 \\
7\end{array}$ & 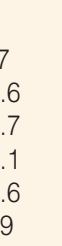 \\
\hline $\begin{array}{l}{ }^{*} \text { General surgery, neurosurgery, surgical oncolog } \\
{ }^{* *} \text { Uulmonology, nephrology, neurology, coronary u } \\
{ }^{* * * H I V} \text { chronic kidney disease, chronic liver disea } \\
{ }^{*} \text { Neuroinfection, soft tissue infection, infected pan } \\
\text { CDI = Clostridium difficile infection. }\end{array}$ & $\begin{array}{l}\text { previou } \\
\text { acterial }\end{array}$ & empyer & & & & & 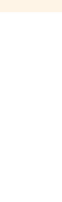 \\
\hline
\end{tabular}

died, $92.9 \%$ had been classified in the complicated disease group $(p=0.001)$ (Table 2).

With regard to age as a risk factor, most patients were between 31 and 60 years, which is the group where more than $50 \%$ of cases occurred. Mortality increase in patients aged $>65$ years was reported with an odds ratio $(\mathrm{OR})=2.46(95 \% \mathrm{Cl}=0.66-9.15$; $p=0.16$ ). Diabetes mellitus was present in $36.5 \%$, and hematological neoplasms and rheumatic diseases in $14.3 \%$ (Table 3).

Regarding the nutritional status, moderate to severe malnourishment was established as an important factor for mortality, with $\mathrm{OR}=20.15(95 \% \mathrm{Cl}=1.13-35$; $p=0.004) ; 87.3 \%$ of the population had some degree of malnourishment: $19 \%$ had mild malnourishment, $50.8 \%$ had moderate malnourishment and $17.5 \%$ had severe malnourishment. With the analysis of biochemical parameters, low levels of albumin were found to be significantly associated with mortality $(p=0.001)$.

As for the history of antibiotic use, $7.9 \%$ of total patients did not have any, $25.4 \%$ required one antibiotic, $36.5 \%$ two and $30.2 \%$, three or more. The main infectious admission diagnoses that required the
Table 2. Association between the degree of severity and in-hospital mortality in patients with CDI

\begin{tabular}{|c|c|c|c|c|c|c|}
\hline \multirow[t]{2}{*}{ Severity } & \multicolumn{2}{|c|}{ Alive patient } & \multicolumn{2}{|c|}{ Dead patient } & \multicolumn{2}{|c|}{ Totel } \\
\hline & $\mathbf{n}$ & $\%$ & $\mathrm{n}$ & $\%$ & n & $\%$ \\
\hline Mild & 22 & 44.9 & 0 & 0.0 & 22 & $\frac{34.9}{0}$ \\
\hline Moderate & 7 & 14.3 & 0 & 0.0 & 7 & t. \\
\hline Severe & 3 & 6.1 & 1 & 7.1 & 4 & 6.3 \\
\hline Severe-complicated & 17 & 34.7 & 13 & $92.9^{*}$ & 30 & 47.6 \\
\hline Total & 49 & 100.0 & 14 & 100.0 & 63 & 100.0 \\
\hline \multicolumn{6}{|c|}{$\mathrm{CDI}=$ Clostridium difficile infection. ${ }^{*} \mathrm{p}=0.001$. } & $\begin{array}{l}\frac{\theta}{\vec{\sigma}} \\
\frac{\hat{\varepsilon}}{\varepsilon}\end{array}$ \\
\hline
\end{tabular}

use of antibiotics were nosocomial pneumonia, urinary tract infection, community-acquired pneumonia, fever and neutropenia, soft tissue infection and neuroinfection. The most commonly used antibiotics were carbapenems in $60.3 \%$, third-generation cephalospprins in $54.4 \%$ and fluoroquinolones in $31.7 \%$. In the subgroup analysis, $93.9 \%$ of alive patients usedtantibiotics, unlike $85 \%$ of patients who died. The use of more than two antibiotics was associated with mortality with an $\mathrm{OR}=1.61(95 \% \mathrm{Cl}=0.39-6.65 ; \mathrm{p}=0.014)$. 
Table 3. Risk factors associated with in-hospital mortality in patients with CDI

\begin{tabular}{|c|c|c|c|c|c|}
\hline \multirow[t]{2}{*}{ Risk factors } & \multicolumn{2}{|c|}{ Alive } & \multicolumn{2}{|c|}{ Dead } & \multirow[t]{2}{*}{ OR (95\% Cl) } \\
\hline & $\mathrm{n}$ & $\%$ & $\mathrm{n}$ & $\%$ & \\
\hline Age $>65$ years & 9 & 18.4 & 5 & 35.7 & $2.46(0.66-9.15)$ \\
\hline $\begin{array}{l}\text { Gender } \\
\text { Male } \\
\text { Female }\end{array}$ & $\begin{array}{l}18 \\
31\end{array}$ & $\begin{array}{l}36.7 \\
63.3\end{array}$ & $\begin{array}{l}5 \\
9\end{array}$ & $\begin{array}{l}36.5 \\
63.4\end{array}$ & $\begin{array}{l}0.95(0.22-3.29) \\
1.04(0.30-3.60)\end{array}$ \\
\hline Moderate-severe malnourishment & 29 & 59.2 & 14 & 100.0 & $20.15(1.13-35)$ \\
\hline Comorbidities & 42 & 85.7 & 12 & 87.5 & $1(0.18-5.46)$ \\
\hline $\begin{array}{l}\text { Antibiotics } \\
>2\end{array}$ & $\begin{array}{l}46 \\
35\end{array}$ & $\begin{array}{l}93.9 \\
71.4\end{array}$ & $\begin{array}{c}12 \\
5\end{array}$ & $\begin{array}{l}85.7 \\
35.7\end{array}$ & $\begin{array}{r}2.55(0.383-17.03 \\
1.61(0.39-6.65)\end{array}$ \\
\hline PPI & 32 & 65.3 & 11 & 78.6 & $0.51(0.12-2.09)$ \\
\hline Steroids & 19 & 38.8 & 3 & 21.4 & $2.32(0.57-9.41)$ \\
\hline Immunosuppressants & 1 & 2.0 & 1 & 7.1 & $0.21(0.01-0.46)$ \\
\hline Chemotherapy & 4 & 8.2 & 2 & 14.3 & $0.53(0.84-3.26)$ \\
\hline Prior hospitalization & 14 & 28.6 & 5 & 26.3 & $0.72(0.20-2.53)$ \\
\hline $\begin{array}{l}\text { Organ failure } \\
\text { Liver failure } \\
\text { Acute kidney injury }\end{array}$ & $\begin{array}{c}13 \\
4 \\
10\end{array}$ & $\begin{array}{c}26.5 \\
8.2 \\
20.4\end{array}$ & $\begin{array}{l}10 \\
7 \\
6\end{array}$ & $\begin{array}{c}71.4 \\
50 \\
42.9\end{array}$ & $\begin{array}{l}1.13(0.31-4.92) \\
0.08(0.02-0.38) \\
0.34(0.09-1.21)\end{array}$ \\
\hline Hypotension & 13 & 26.5 & 13 & 92.9 & $1.28(0.30-1.23)$ \\
\hline Stay $>15$ days & 39 & 79.6 & 12 & 85.7 & $0.65(0.12-3.38)$ \\
\hline
\end{tabular}

$\mathrm{CDI}=$ Clostridium difficile infection; $\mathrm{PPI}=$ proton pump inhibitors .

Proton pump inhibitors were used in $68.3 \%$ of patients, in $78.6 \%$ in the group of patients who died versus $65.3 \%$ of alive patients $(p=0.35)$. Steroids were administered in $34.9 \%$ of the population, in $21.4 \%$ of patients who died versus $38.8 \%$ of alive patients $(p=0.23)$. Immunosuppressants (azathioprine and mycophenolate mofetil) were prescribed to $3.2 \%$ of the population, in $2 \%$ of the alive patient group and in $7.1 \%$ of those who died $(p=0.34)$. Chemotherapy was received by $9.5 \%$ of patients, $8.2 \%$ of alive patients versus $14.3 \%$ of those who died ( $p=0.491)$.

Acute kidney injury, as determined by AKIN criteria, was not associated with increased mortality $(p=0.34)$. However, specifically, creatinine levels elevation (with a mean of $0.92 \pm 1.09 \mathrm{mg} / \mathrm{dL}$ in the group of alive patients versus $2 \pm 2.9 \mathrm{mg} / \mathrm{dL}$ in the group of patients who died) was related to mortality, with an $\mathrm{OR}=1.34(95 \% \mathrm{Cl}=0.09-2.21 ; \mathrm{p}=0.02)$ (Table 4).

Mean hospital stay was $37 \pm 35.3$ days, with ranges between four and 203 days. Alive patients had a mean hospital stay of $38.71 \pm 32.39$ days, in comparison with $31.14 \pm 18.7$ days in those who died $(p=0.27)$. Procalcitonin levels had a considerable mean difference: $1.62 \pm 2.83 \mathrm{ng} / \mathrm{mL}$ in the group of alive patients versus $8.46 \pm 11.5 \mathrm{ng} / \mathrm{mL}$ in the group of patients who died.
Table 4. Biochemical risk factors associated with in-hospital mortality in patients with CDI

\begin{tabular}{|c|c|c|c|}
\hline \multirow[t]{2}{*}{ Parameter } & Alive & Dead & \\
\hline & Mean \pm SD & Mean \pm SD & \\
\hline Albumin (g/dL) & $2.76 \pm 0.63$ & $2.21 \pm 0.3 \mathrm{~g} / \mathrm{dL}$ & 201 \\
\hline Leukocytes $/ \mathrm{mm}^{3}$ & $10698 \pm 8.19$ & $9907 \pm 9.41$ & 5 \\
\hline Neutrophils/mm $\mathrm{mm}^{3}$ & $7970 \pm 5.41$ & $8200 \pm 9.04$ & 2 \\
\hline Lymphocytes $/ \mathrm{mm}^{3}$ & $1877 \pm 54$ & $527 \pm 43$ & \\
\hline Hemoglobin (mg/dL) & $9.8 \pm 2.41$ & $8.6 \pm 1.38$ & \\
\hline Hematocrit (\%) & $30.9 \pm 2.4$ & $26.6 \pm 1.38$ & 2 \\
\hline Procalcitonin (ng/mL) & $1.62 \pm 2.83$ & $8.46 \pm 11.5$ & \\
\hline Creatinine (mg/dL) & $0.92 \pm 1.09$ & $2 \pm 2.9$ & \\
\hline BUN (mg/dL) & $22.8 \pm 19.5$ & $44.93 \pm 32.2$ & \\
\hline Sodium (mEq/L) & $138 \pm 5.7$ & $140 \pm 7.5$ & 0.41 \\
\hline Potassium (mEq/L) & $3.83 \pm 0.67$ & $3.49 \pm 0.67$ & 0 \\
\hline
\end{tabular}

Other parameters that were associated with a mortality increase were hypotension, which required the use of vasopressors in $26.5 \%$ of alive patients versus $92.9 \%$ of those who died $(\mathrm{OR}=1.28 ; 95 \% \mathrm{Cl}=0.30-1.23$, 
$\mathrm{p}=0.001$ ) and multiple organ failure development in $26.5 \%$ of alive patients versus $71.4 \%$ of those who died $(\mathrm{OR}=1.13 ; 95 \% \mathrm{Cl}=0.31-4.92 ; \mathrm{p}=0.002)$. Although in $50 \%$ of the patients who died, an elevation in liver function tests was observed, in comparison with $8.2 \%$ in the group of alive patients, the difference was not statistically significant $(p=0.08)$.

Comorbidities, previous use of antibiotics, previous history of hospitalizations and use of proton pump inhibitors, steroids, immunosuppressants or chemotherapy were not significantly associated with the outcome.

Treatment was determined considering the degree of severity: $47.6 \%$ received oral metronidazole, $500 \mathrm{mg}$ every eight hours, as first line of treatment; $33.3 \%$ received oral vancomycin, $125 \mathrm{mg}$ every six hours, and $17.5 \%$ received combined treatment with intravenous metronidazole and oral vancomycin. Treatment duration was $7.0 \pm 3.49$ days.

\section{Discussion}

CDI morbidity and mortality has become a major health problem due to its increased incidence in recent years. In our study, we found a higher CDI incidence than that reported in the literature, which may be related to the diagnosis of hospital diarrhea and to the difficulty to access to diagnostic methods in hospital units. ${ }^{11}$ An advantage in our institution is the access to different microbiological diagnostic methods, in addition to having a protocol for cases of diarrhea suspicious of CDI, which allows timely diagnosis and treatment.

Mortality reported for CDI has significantly increased, with various cohort analyses estimating it between 17 and $25 \% .^{12}$ Ramírez et al. ${ }^{7}$ indicate a mortality of $9.1 \%$ (lower than that found by us), while Dávila et al..$^{13}$ record $22.7 \%$, which is similar to ours. These differences may be secondary to the type of hospital where the studies took place, since the first one was carried out in a private hospital.

The distribution regarding the different hospital departments indicates higher detection in clinical departments such as internal medicine and geriatrics, in comparison with surgical departments, probably due to $\mathrm{CDI}$ underdiagnosis. Although the geriatric population is described as being at higher risk, both for CDI and mortality, we did not find age to be a factor associated with mortality, even when several patients were classified in this age group, which differs from observations published by other authors. ${ }^{14}$ This can be attributed to early diagnosis, close monitoring and resolution of complications.

The presence of moderate to severe malnouishment is associated with in-hospital mortality, similar to the findings in a Spanish investigation where increased mortality related to immunosuppression secondary to malnourishment is described, as well as a decrease in patients' functional reserve. ${ }^{15}$ Energy and protein losses due to diarrhea cause significant deficit, despite the use of antibiotics, which results in the block of immune response.

Underlying disease is another important factor,gjust as treatment. Metabolic conditions favor the appearance of infections and cause a secondaryimmunosuppression state; in turn, neoplastic diseases require the use of cytotoxic drugs.

The use of antibiotics up to three months prior to hospitalization is considered a risk factor for CDI, the most commonly related antibiotics were cephalosporins, fluoroquinolones and any penicillin. ${ }^{12}$ Dutring hospital stay, $92.1 \%$ of patients had an infectious condition, such as associated pneumonia, whichentailed the use of broad spectrum antibiotics. In our study, the most commonly used antibiotics were carbapenems, third-generation cephalosporins and fluoroquinolones. Although Velarde et al. ${ }^{16}$ found no association of the number of antibiotics with disease severity or mortality, we observed an increase in mortality with the use of more than two antibiotics.

The use of proton pump inhibitors has also been described as a risk factor, with an increase of up to $65 \%$ in the incidence of $\mathrm{CDI} .{ }^{17}$ Although in our study we did not establish a significant relationship within increased mortality, we consider that the prescription of proton pump inhibitors in hospitalized patients should be done with caution, since there is evidence pointing at the use of this type of drugs as a risk factor. The use of steroids was also not associated with mortality. History of hospitalization up to 90 days prior is considered a risk factor for CDI, especially if it is associated with previous consumption of antibiotics, althotigh Leibovici et al..$^{18}$ failed to identify any significant relationship with CDI mortality either, similar to our recorded observations.

During CDI clinical evolution, hypotension and organ failure were directly associated with mortality, mainly with early mortality in less than 7 days. Leibovici et al. $^{18}$ indicate that hypotension can increase mortality in patients with CDI due to a higher risk of myocardial infarction and septic shock, with the latter also having been associated with early mortality. 
Increases in liver function tests were higher in the group of patients who died; however, these parameters had no direct, significant association with mortality. As for severity, a significant association was observed with mortality in patients classified with severe or severe-complicated disease, which is explained by the higher incidence of septic shock and organ failure, as well as by malnourishment-derived immunosuppression and decreased serum albumin with lower functional reserve and risk of complications added.

Some studies suggest that procalcitonin determination may be useful for assessing severity and prognosis in patients with $\mathrm{CDI}$; a level $>0.5$ has been reported to be a marker for identifying severe $\mathrm{CDI},{ }^{19}$ but not for mortality. ${ }^{20}$ In a study published by Dazle, ${ }^{20}$ a procalcitonin level $>0.05$ was observed to be a marker to identify serious CDI, whereas Shapiro ${ }^{19}$ reports that levels $>2 \mathrm{mg} / \mathrm{mL}$ are associated with $\mathrm{CDI}$, but not with severity or mortality. In our study, we identified a significant borderline association between procalcitonin values and mortality, which indicates that further studies are required to clarify the role of procalcitonin in CDI.

Monge et al..$^{15}$ indicate that CDI significantly and independently prolongs hospital stay, and that this is directly associated with disease severity, which is similar to observations reported by Ramírez et al. ${ }^{7}$ In our study we did not observe that tendency, not even in the group of geriatric patients; we consider that first-line drug treatment timely start was decisive for these results.

First-line treatment for $\mathrm{CDI}$ is based on disease severity and includes metronidazole and vancomycin, with few secondary therapeutic options being available..$^{12}$ In cases of mild to moderate disease, we use oral metronidazole, and for those with severe disease, oral vancomycin. Regarding the latter, since in Mexico this type of presentations are not available, a 500-mg parenteral vial was fractioned to orally administer $125 \mathrm{mg}$ diluted in juice or by nasogastric tube, in order to achieve high levels of the drug in the colon, with partial absorption, and to preserve physiological intestinal flora. The treatment success rate reported in the literature is $75 \%$;21 however, in our study we recorded $83.4 \%$ in patients treated with metronidazole. This is probably due to early diagnosis and timely intervention.

We conclude that CDI constitutes an important problem in hospitalized patients: it confers additional morbidity and mortality risk, with an increase in hospital costs. Moderate to severe malnourishment, the use of more than two antibiotics, acute kidney injur hypotension with vasopressor use and multiple organ failure were associated with in-hospital mortality increase in patients with $\mathrm{CDI}$, which justifies intensifying preventive measures and risk-factor identificatio $\mathrm{P}$ for its correction.

\section{References}

1. Lopardo G, Morfin-Otero R, Morán-Vázquez II, Noriega F, Zambraño B, Luxemburger $\mathrm{C}$, et al. Epidemiology of clostridium difficile: a hospitat-based descriptive study in Argentina and Mexico. Braz J Infect Dis. 2015 ; 19:8-14.

2. Riddle DJ, Dubberke ER. Clostridium difficile infection in the intensive care unit. Infect Dis Clin North Am. 2009;23:727-743.

3. Vindigni SM, Surawicz CM. C. difficile infection: changing epidemiglogy and management paradigms. Clin Transl Gastroenterol. 2015;6:e99.

4. Lessa FC, Gould CV, McDonald LC. Current status of clostridium difficile infection epidemiology. Clin Infect Dis. 2012;55:S65-S70.

5. Freeman J, Bauer MP, Baines SD, Corver J, Fawley WN, Goorhuis B, et al. The changing epidemiology of clostridium difficile infections.-Clin Microbiol Rev. 2010;23:529-549.

6. Carroll KC, Bartlett JG. Biology of clostridium difficile: implications for epidemiology and diagnosis. Annu Rev Microbiol. 2011;65:501-521.

7. Ramírez-Rosales A, Cantú-Llanos E. Intrahospital mortality in pattents with Clostridium difficile-associated diarrhea infection. Rev Gastroenterol Mex. 2012;77:60-65

8. Meyer SL, Espinoza AR, Quera PR. Infección por Clostridium difficilè epidemiología, diagnóstico y estrategias terapéuticas. Rev Med Clin. 2014;25: 473-484.

9. Loo VG, Bourgault AM, Poirier L, Lamothe F, Michaud S, Turgéon N, et al. Host and pathogen factors for Clostridium difficile infection and colonization. N Engl J Med. 2011;365:1693-1703.

10. Kazanowski M, Smolarek S, Kinnarney F, Grzebieniak Z. Clostrídium difficile: epidemiology, diagnostic and therapeutic possibilities: a' systematic review. Tech Coloproctol, 2014;18:223-232.

11. Steiner C, Barrett M, Weiss A. HCUP Projections: Clostridium difficile hospitalizations 2003-2014. HCUP Projections Report \# 2014-05. EE. UU.: Agency for Healthcare Research and Quality; 2014.

12. Feuerstadt $P$, Das R, Brandt LJ. The evolution of urban $C$. difficile tion (CDI): CDI in 2009-2011 is less severe and has better outcomes than CDI in 2006-2008. Am J Gastroenterol. 2014;109:1265-1276.

13. Dávila LP, Garza-González E, Rodríguez-Zulueta P, Morfín-Otero R, Rodríguez-Noriega E, Vilar-Compte D, et al. Increasing rates of Etostridium difficile infection in Mexican hospitals. Braz J Infect Dis. 2017 ; 21:530-534.

14. DePestel DD, Aronoff DM. Epidemiology of Clostridium difficile infection. J Pharm Pract, 2013;26:464-475.

15. Monge D, Millán I, González-Escalada A, Asensio A. The effect of Ċlostridium difficile infection on length of hospital stay. A cohort study. Enferm Infecc Microbiol Clin. 2013;31:660-664.

16. Velarde-Ruiz-Velasco JA, Aldana-Ledesma JM, Ibarra-Estrada MA Ǎ Aquirre-Díaz SA, Fernández-Ramírez JA, Cárdenas-Lara F, et al. Clinical and endoscopic features in patients with hospital-acquired diarrhea associated with Clostridium difficile infection. Rev Gastroenterol Mex. 2017; 82:301-308.

17. Janarthanan S, Ditah I, Adler DG, Ehrinpreis MN. Clostridium difficite-associated diarrhea and proton pump inhibitor therapy: a meta-analysis. Am J Gastroenterol. 2012;107:1001-1010.

18. Leibovici-Weissman $\mathrm{Y}$, Atamna A, Schlesinger A, Eliakim-Raz N, Bishara J, Yahav D. Risk factors for short-term and long-term mortality in very old patients with Clostridium difficile infection: a retrospective study. Geriatr Gerontol Int. 2017:17:1378-1383.

19. Shapiro DS, Friedmann R, Husseini A, Ivgi H, Yinnon AM, Assou@ MV Can procalcitonin contribute to the diagnosis of Clostridium difficilecolitis? Isr Med Assoc J. 2017;19:313-316.

20. Dazley J, Shaaban H, Afridi S, Slim J. The role of procalcitonin levels in assessing the severity of Clostridium difficile infection. J Glob Infect Dis. 2015;7:120-121

21. Gardilcic M, Fica A, Chang M, Llanos C, Luzoro A. Diarrea asociada a Clostridium difficile en un hospital de adultos: estudio descriptivo.-Rev Chil Infectol. 2000;17:307-312. 